University of Nebraska - Lincoln

DigitalCommons@University of Nebraska - Lincoln

Egyptian textiles and their production: 'word' and 'object'

Centre for Textile Research

$3-2-2020$

\title{
Frontmatter for Egyptian textiles and their production: 'word' and 'object'. (Hellenistic, Roman and Byzantine periods)
}

Maria Mossakowska-Gaubert

University of Copenhagen

Follow this and additional works at: https://digitalcommons.unl.edu/egyptextiles

Part of the Africana Studies Commons, African Languages and Societies Commons, Classical Archaeology and Art History Commons, Fiber, Textile, and Weaving Arts Commons, History of Art, Architecture, and Archaeology Commons, and the History of Science, Technology, and Medicine Commons

Mossakowska-Gaubert, Maria, "Frontmatter for Egyptian textiles and their production: 'word' and 'object'. (Hellenistic, Roman and Byzantine periods)" (2020). Egyptian textiles and their production: 'word' and 'object'. 1.

https://digitalcommons.unl.edu/egyptextiles/1

This Article is brought to you for free and open access by the Centre for Textile Research at DigitalCommons@University of Nebraska - Lincoln. It has been accepted for inclusion in Egyptian textiles and their production: 'word' and 'object' by an authorized administrator of DigitalCommons@University of Nebraska - Lincoln. 
Maria Mossákows la Caubert (ed)

Igytian textiles

and their productionel

word and oloject?

(Hellenistid, Roman and Byzantine periods)

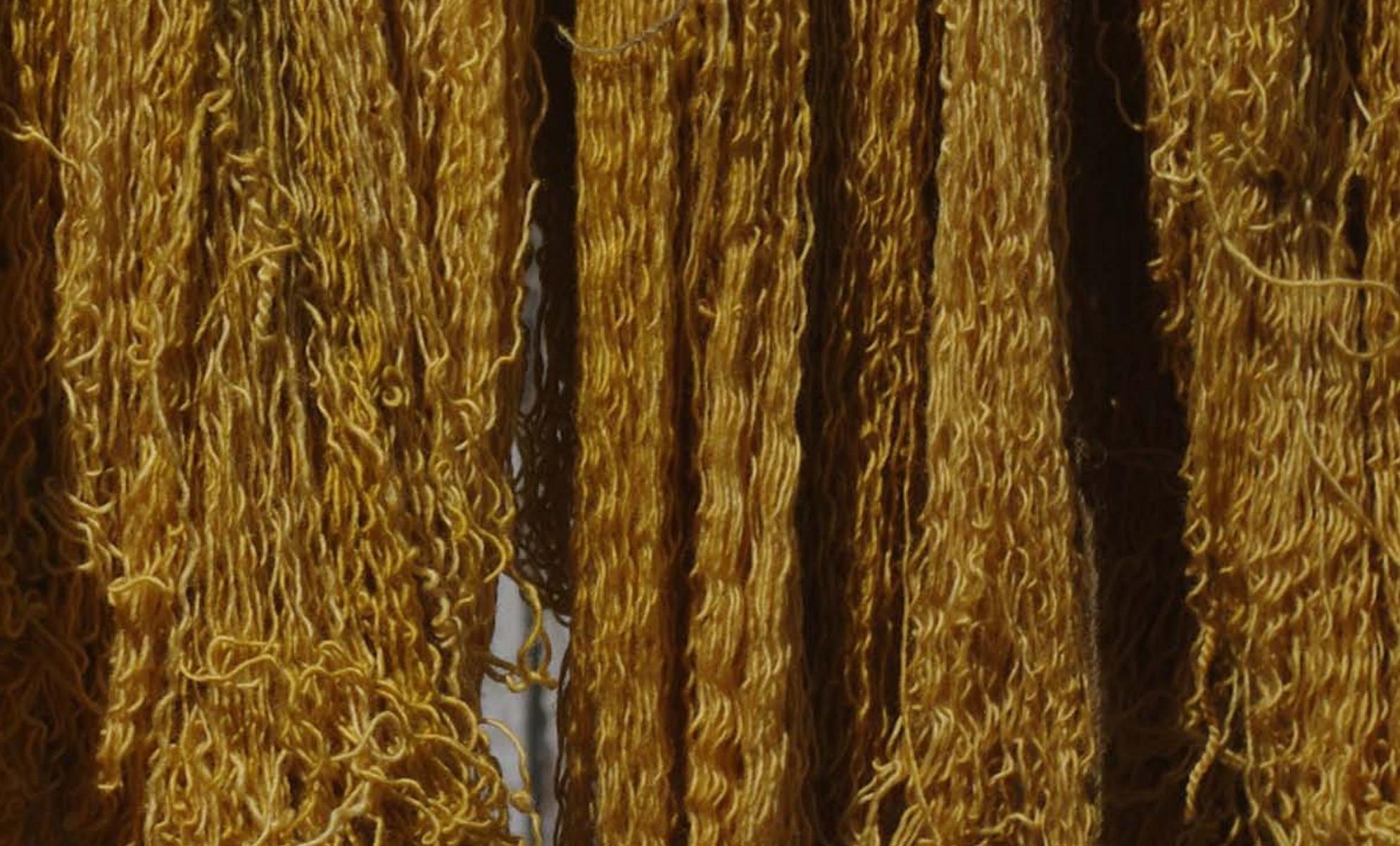


This volume presents the results of a workshop that took place on 24 November 2017 at the Centre for Textile Research (CTR), University of Copenhagen. The event was organised within the framework of the MONTEX project-a Marie Skłodowska-Curie individual fellowship conducted by Maria Mossakowska-Gaubert in collaboration with the Contextes et Mobiliers programme of the French Institute for Oriental Archaeology in Cairo (IFAO), and with support from the Institut français du Danemark and the Alexander von Humboldt Foundation.

Twelve essays are arranged in 4 sections: I. Weaving looms: texts, images, remains; II. Technology of weaving: study cases; III. Dyeing: terminology and technology; IV. Textile production in written sources: organisation and economy.

Contributors include: Maria Mossakowska-Gaubert, Johanna Sigl, Fleur Letellier-Willemin, Lise Bender Jørgensen, Anne Kwaspen, Barbara Köstner, Peder Flemestad, Ines Bogensperger \& Helga Rösel-Mautendorfer, Isabelle Marthot-Santaniello, Aikaterini Koroli, Kerstin Dross-Krüpe, Jennifer Cromwell, and Dominique Cardon. With 66 full-colour illustrations.

Cover photo: Large fabric and yarns dyed in the same dye bath @ Helga Rösel-Mautendorfer.

Zea Books

Lincoln, Nebraska 
Maria Mossakowska-Gaubert (ed.)

Egyptian textiles

and their production:

'word' and 'object'

(Hellenistic, Roman and Byzantine periods)

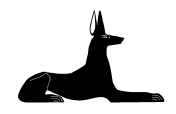

Zea Books

Lincoln, Nebraska 2020 
Texts copyright (C) 2020 by the authors.

Volume copyright (c) 2020 Maria Mossakowska-Gaubert.

ISBN: 978-1-60962-153-7

doi 10.32873/unl.dc.zea.1077

Composed in Sitka, IFAO Greek, and Rockwell types.

Zea Books are published by the University of Nebraska-Lincoln Libraries.

\author{
Electronic (pdf) edition available online at \\ https://digitalcommons.unl.edu/zeabook/ \\ Print edition available from \\ http://www.lulu.com/spotlight/unllib
}

UNL does not discriminate based upon any protected status.

Please go to http://www.unl.edu/equity/noitce-nondiscrimination

\title{
Nebrask Lincoln
}

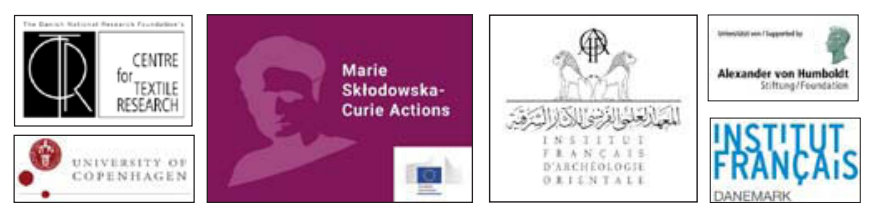




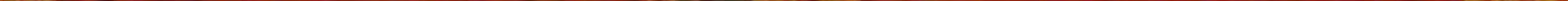




\section{Contents:}

Maria Mossakowska-Gaubert

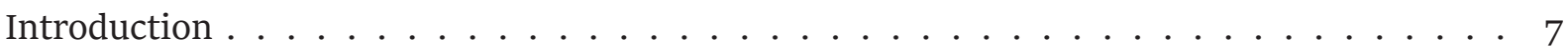

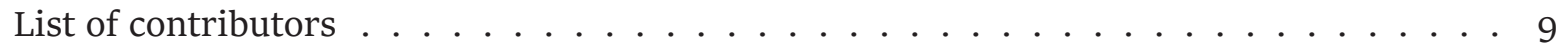

Part I.Weaving looms: texts, images, remains

Maria Mossakowska-Gaubert

A new kind of loom in Roman Egypt? How iconography could explain (or not)

papyrological evidence . . . . . . . . . . . . . . . . . . 13

Johanna Sigl

Egyptian pit-looms from the late $1^{\text {st }}$ millennium $\mathrm{AD}$ - attempts at reconstruction

from the archaeological evidence . . . . . . . . . . . . . . 22

\section{Part II. Technology of weaving: study cases}

Fleur Letellier-Willemin

Tackling the technical history of the textiles of El-Deir, Kharga Oasis, the Western Desert of Egypt . . . . . . . . . . . . . . 37

Lise Bender Jørgensen

Textiles from a Late Roman/Byzantine ecclesiastical centre at Abu Sha'ar, Egypt . . . . . 49

Anne Kwaspen

Reconstruction of a deconstructed tunic . . . . . . . . . . . . . . . 6o

\section{Barbara Köstner}

What flaws can tell: a case study on weaving faults in Late Roman and Early

Medieval weft-faced compound fabrics from Egypt . . . . . . . . . . . . . 69

\section{Part III. Dyeing: terminology and technology}

\section{Peder Flemestad}

Ancient Greek dyeing: a terminological approach . . . . . . . . . . . . . . 82

- Ines Bogensperger \& Helga Rösel-Mautendorfer

Dyeing in texts and textiles: words expressing ancient technology . . . . . . . . . . 91 
Part IV. Textile production in written sources: organisation and economy

Isabelle Marthot-Santaniello

Flax growing in late antique Egypt: evidence from the Aphrodito papyri. . . . . . . . 107

Aikaterini Koroli

Textile production in the papyri: the case of private request letters $\ldots \ldots$. . . . 116

Kerstin Dross-Krüpe

How (not) to organise Roman textile production. Some considerations on

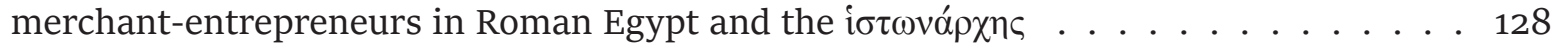

Jennifer Cromwell

Domestic textile production in Dakhleh Oasis in the Fourth century AD . . . . . . . 139

\section{- Dominique Cardon}

Conclusion . . . . . . . . . . . . . . . . . . . 153 


\section{Introduction}

\section{Maria Mossakowska-Gaubert}

This volume presents the results of a workshop, which took place on 24 November 2017 at the Centre for Textile Research (CTR), University of Copenhagen. The event was organised within the framework of the MONTEX project ${ }^{1}-\mathrm{a}$ Marie Skłodowska-Curie individual fellowship conducted by Maria Mossakowska-Gaubert in collaboration with the Contextes et Mobiliers programme of the French Institute for Oriental Archaeology in Cairo (IFAO), and with support from the Institut français du Danemark and the Alexander von Humboldt Foundation.

Bringing together archaeologists, historians, philologists and papyrologists, this work compares different points of view on raw materials, looms, the technology of weaving and dyeing, as well as the organisation of textile production in Egypt in the Hellenistic, Roman and Byzantine periods. It also involves an attempt to identify a "word" with an "object". Indeed, when an "archaeological object" is mentioned, what first comes to mind are its form, the way it is produced and decorated, and lastly the way in which it is used. It is quite unusual for archaeological publications to ask what the object was called. Meanwhile, both literary and documentary texts offer an exceptional abundance of words defining such items. However, the lexicographical interpretation of the terms proposed in dictionaries does not always correspond with the chronological, geographical, or technological realities that determined the production and usage of the investigated artefacts.
In order to provide answers to some of these issues, the present volume includes new material from excavations with innovative interpretations, recent studies on material from collections, experimental dyeing and weaving investigations, presentations of iconographical material, as well as historical and sociological studies based on papyrological documentation and literary texts. It also contains lexicographical research into Greek and Coptic vocabulary.

The subject of the provision of raw materials leads to questions regarding flax growing (Isabelle MarthotSantaniello). The cultivation of flax was without any doubt widespread in Egypt throughout antiquity, but compared to wheat or barley, there are very few records in documentary texts of flax being grown.

An identification of weaving looms needing a special pit in which to set them (Johanna Sigl), a discussion of an overlooked image of a specific kind of loom on a painted tunic from Saqqara, as well as an enquiry into the varied Greek vocabulary concerning looms and specialised weavers (Maria Mossakowska-Gaubert) all reflect technological developments and innovations in the domain of weaving. In addition, the issue of the technique and the looms for silk samite from Late Roman and Early Medieval Egypt is connected to questions about the origin of these textiles (Barbara Köstner).

Testimony from papyrological texts combined with experimental archaeology could provide new data about

Published in Maria Mossakowska-Gaubert, ed., Egyptian textiles and their production: 'word' and 'object' (Hellenistic, Roman and Byzantine periods) (Lincoln, NE: Zea Books, 2020). doi 10.32873/unl.dc.zea.1078

1 Montex: Monks, Nuns AND Textiles: Production, Circulation, and Distribution of Textiles in the Monastic Environment in Egypt $\left(4^{\text {th }}-8^{\text {th }}\right.$ Centuries AD): This project has received funding from the European Union's Horizon 2020 research and innovation programme under the Marie Skłodowska-Curie grant agreement No 701479. Project is hosted by the University of Copenhagen (Saxo-Institute: CTR), and its secondment institution is the Université Paris Ouest - Nanterre La Défense (France). 
another branch of textile technology and industry: dyeing (Ines Bogensperger and Helga Rösel-Mautendorfer). What's more, dyeing or dyed fabrics are very often mentioned in Greek literature, and the related vocabulary is very rich (Peder Flemestad).

Textiles found on the "margins" of Egypt-Abu Sha'ar on the Red Sea (Lise Bender Jørgensen) and El-Deir in Kharga Oasis (Fleur Letellier-Willemin)-shed new light on fibres (linen, wool, cotton), various decorative techniques as tapestry or taqueté, as well as on the sociological context of textile use.

We have some information about the organisation of textile production and trade in an oasis environment from papyrological documentation. This documentation also provides a reach vocabulary of textile industry (Jennifer Cromwell). Request papyrus letters, being a separate epistolary category, give testimony about various aspects of textile production and use in late antique Egypt (Aikaterini Koroli). In addition, the question of the function of an

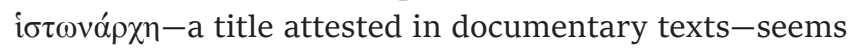
to be crucial to understanding the organising system of professional textile production in Roman Egypt (Kerstin Droß-Krüpe).

Lastly, when talking about the production of a garment, one should mention the practice of reusing finished garments to create other garments. Completely new data about this phenomenon are provided by the analysis of a tunic preserved in the Louvre (Anne Kwaspen).

Alongside economic and sociological elements, all of these studies, dealing with the history of techniques, technology and work organisation, the provision of raw materials, and the appearance of looms, combine all the categories of written, archaeological and occasionally iconographic sources, in order to bring new elements to the "puzzle" of the economic and social history of Egypt, as well as opening new research perspectives.

\section{Acknowledgments}

I would like to thank all the partner institutions whose support enabled me to organise the workshop in November 2017. My special thanks go to colleagues and friends from the University of Copenhagen: Eva Andersson-Strand, Marie-Louise Nosch, Magdalena Öhrman, Sandy Rizvic as well as Carsten Holt, whose dedication allowed the workshop to take place on the scheduled date.

I would like to thank all the participants of the event and invited authors for their important contributions. My particular thanks go to Dominique Cardon, one of the participants of the workshop, for agreeing to write a Conclusion to the present book. I am grateful to both of our referees, who must remain anonymous, for devoting their time and their knowledge in commenting on the articles submitted for publication.

I would also like to thank Colin Clement for verifying the English throughout the book. This publication was made possible thanks to the wonderful cooperation with Zea Books and their editor Paul Royster.

This book is published with the financial support of the MONTEX programme and the IFAO. 


\section{Contributors}

Lise Bender Jørgensen is Emerita Professor of Archaeology at the Norwegian University of Science and Technology in Trondheim. A Danish national, she studied archaeology at the University of Copenhagen. Before moving to Norway, she had a spell of teaching archaeology at Göteborg University in Sweden, and later held an adjunct professorship in textile science at the University of Borås in Sweden. She has excavated in Scandinavia, Egypt and Turkey, and has travelled widely in Europe recording archaeological textiles. She is the author of two monographs on Scandinavian and North European textiles from their beginnings up to $1000 \mathrm{AD}$, co-author of a volume on creativity in the Bronze Age and of three volumes publishing excavations of Viking age and renaissance sites in Denmark. She is one of the founders of the North European Symposium of Archaeological Textiles and has directed and participated in research projects on Roman textiles from Egypt, on wool sails for Viking ships, and on how to deal with non-discursive knowledge in textile craftsmanship. She is currently working on Neolithic textiles from Çatalhöyük in Turkey.

Ines Bogensperger studied classical archaeology at the University of Vienna, Austria. She is currently a PhD candidate in ancient history. During her work at the Papyrussammlung of the Austrian National Library, Vienna, she gained experience in the field of late antique textiles from Egypt as part of the research project forMuse. Her exploration of the evidence regarding textiles in documentary papyri, combining textile research with papyrology, was supported by a research grant-Texts and Textiles in Late Antique Egypt-from the Austrian Research Fund. In addition, she launched the initiative Ancient TextilesModern Hands to engage a broader public audience in textile research. She has organised several exhibitions and lectures to build relationships between academia and textile artists.

Dominique Cadron is a senior scientific researcher with the French National Centre of Scientific Research (CNRS), research unit CIHAM/UMR 5648, Lyon, France. She received the CNRS silver medal in 2011. Her long-pursued research themes are the history and archaeology of textile production and dyeing. She has studied and published series of archaeological textiles, including textiles from six Roman praesidia and a Hellenistic gold mine site in the Eastern Desert of Egypt, and textiles from Bronze Age and Iron Age sites in the Taklamakan desert, excavated by the Franco-Chinese archaeological mission of Xinjiang. D. Cardon is the author of several books on natural dyes, one of which received the L'Oréal Foundation's Art and Science of Colour Prize in 2003. As scientific director of the International Symposium/Workshop on Natural Dyes in India, Korea, Taiwan, France, Madagascar and recently China, she was awarded the UNESCO medal "Thinking and Building Peace” in 2006. She was made Chevalier de la Légion d'Honneur in France in 2015 and Chevalier de l'Ordre des Arts, des Lettres et de la Culture of Madagascar in 2017.

Jennifer Cromwell is a lecturer in ancient history and member of the Manchester Centre for Youth Studies at Manchester Metropolitan University. Previously, she has held research positions in the University of Oxford, Macquarie University (Sydney), and the University of Copenhagen, where she was a Marie Skłodowska-Curie Research Fellow. Her research interests broadly lie in the social and economic history of Egypt from the $4^{\text {th }}$ to $8^{\text {th }}$ centuries AD, with particular focus on the evidence provided by Coptic 
non-literary texts. She is the author of Recording Village Life: A Coptic Scribe in Early Islamic Egypt (Ann Arbor, 2017) and co-editor of Scribal Repertoires in Egypt from the New Kingdom to the Early Islamic Period (with Eitan Grossman; Oxford, 2017) and Ptolemy I and the Transformation of Egypt, 404-282 BCE (with Paul McKechnie; Leiden, 2018).

Kerstin Droß-Krüpe is currently a post-doctoral assistant at Kassel University. She studied classical archaeology, ancient history and business administration at PhilippsUniversität Marburg and obtained her PhD in 2010 with a thesis concerning textile production during the Roman Empire in the province of Egypt, published as Wolle - Weber - Wirtschaft. Die Textilproduktion der römischen Kaiserzeit im Spiegel der papyrologischen Überlieferung (Wiesbaden 2011). In 2014 and 2016 she edited several volumes on ancient economic history: Textile Trade and Distribution in Antiquity (Wiesbaden 2014), Textiles, Trade, and Theories (Münster 2016, with Marie-Louise Nosch), The Cultural Shaping of the Ancient Economy (Wiesbaden 2016, with Sabine Föllinger and Kai Ruffing). Her current research project deals with the reception of the "Babylonian" queen Semiramis in Baroque opera.

Peder Flemestad is a classical philologist. He is currently a PhD candidate at Lund University, Sweden, and an affiliated researcher at the Centre for Textile Research at the University of Copenhagen, Denmark; his project investigates issues of dress and identity in Imperial Greece. He has previously held various teaching and research positions at the University of Copenhagen (2005-2016), and has worked for the Tracking Colour project at the Ny Carlsberg Glyptotek. His research interests include ancient Greek and Latin language and literature, ancient history and epigraphy, Indo-European studies, and diachronic terminology.

Aikaterini Koroli is a papyrologist, philologist and linguist. She studied Greek philology at the University of Athens. She holds a master's degree in educational linguistics and a doctorate in classics and papyrology from the same university. The topic of her thesis, published in 2016, is the text-linguistic analysis of the act of requesting in private correspondence preserved on papyri and ostraca of the Roman, Byzantine and Early Arab periods of Egypt. From September 2015 to January 2019 she worked as a researcher with the Austrian Science Fund project Texts and Textiles from Late Antique Egypt (with Bernhard Palme and Ines Bogensperger) in affiliation with the Austrian Academy of Sciences. She currently holds a Hertha Firnberg Fellowship at the University of Vienna (project title: Business Letters from Byzantine Egypt. First Edition and Linguistic Analysis of twenty five Greek Papyri). Her publications so far deal with Greek papyrology, ancient and late antique Greek literature, text-linguistics, social and economic history, as well as the material culture of late antiquity.

Barbara Köstner is a textile archaeologist with a master's degree in archaeology of the Roman Provinces (main subject), Early Christian archaeology, ancient history and sociology (Universities of Cologne and Bonn). Her PhD project, Complex Silk fabrics from the area of the Roman Empire from Late Roman and Early Medieval times, examines different fabrics, such as taqueté and samite, in order to shed light on questions of the production, trade and consumption of these textiles. Her focus is on textile techniques and the transfer of fabrics and weaving technologies between Asia and Europe in Late Roman times. As a freelance textile archaeologist she has presented courses at universities and museums, where she endeavours to convey complex textile processes to students and audience thanks to her practical experience. In 2016, she was a Veronika Gervers Research Fellow at the Royal Ontario Museum, Toronto.

Anne Kwaspen trained as a textile artist and created contemporary textile artworks before beginning additional studies in tailoring techniques. For six years she worked for leading Belgian fashion designers, while training in textile conservation. As head of the Fashion Museum Hasselt she conveyed her knowledge of historical costume through exhibitions on fashion history. In 2007 she became conservator of Egyptian archaeological textiles at the Phoebus Foundation in Antwerp where she specialised in the technical analysis of textiles. Within the study of archaeological clothing finds, her previous work and experience bring an additional perspective in which the combination of technical analysis and the analysis of tailoring provides an insight on how the shape of garments has been established. She gained fieldwork experience as a textile specialist for the Brigham Young University, USA, excavation team working on textiles unearthed at Fag el-Gamus. In the coming years, she will conduct research on early medieval Egyptian tunics as a Marie Skłodowska-Curie Research Fellow at the University of Copenhagen, Saxo Institute - Centre for Textile Research.

Fleur Letellier-Willemin is a medical doctor and radiologist, a researcher in physical anthropology and a specialist in the field of X-ray use in archaeological research. She is an associate researcher with the CRIHAM EA 4270 team of Limoges University, and a member of the French archaeological team on the site of El-Deir, Kharga Oasis, 
in Egypt's Western Desert where she is responsible for studying textiles found during excavations. She was also involved in the MAHES research programme (Momies Animales et Humaines Égyptiennes) at Montpellier University. As part of this project she studied textiles from animal mummies conserved at the Musée des Confluences, Lyon. She has also conducted research in physical anthropology with Jean-Louis Heim (Musée de l'Homme, Paris) and has X-rayed mummies in the field at El-Deir with Roger Lichtenberg.

Isabelle Marthot-Santaniello was trained in both classics and ancient history in Paris (Sorbonne) before focusing on Greek and, to a lesser extent, Coptic papyrology at the École Pratique des Hautes Études for her master's and PhD qualifications. A first post-doctoral post in the University of Minnesota introduced her to the field of digital papyrology. Since September 2015, she has been scientific collaborator in the Department of Ancient Civilisations at the University of Basel where she took part in the (re-)edition of the Basel papyrus collection (forthcoming P. Bas. II), and in the multidisciplinary research project Change and Continuities from a Christian to a Muslim Society - Egyptian Society and Economy in the 6th to 8th centuries. Since September 2018, she has been a leader of a project funded by the Swiss National Science Foundation and hosted at the University of Basel: d-scribes.org Digital Palaeography of Greek and Coptic Papyri. Her main fields of expertise are the edition and commentary of documentary papyri from late antique Egypt ( $4^{\text {th }}$ to $8^{\text {th }}$ centuries AD), the village of Aphrodito and, more recently, computerised approaches to ancient handwriting on papyri.

Maria Mossakowska-Gaubert, archaeologist and historian, is a graduate of the University of Warsaw. A former assistant curator at the National Museum of Warsaw, Department of Oriental Christian Art (1993-1999), from 1999 to 2003 she was an externally supported scientific fellow at the French Institute of Oriental Archaeology in Cairo (IFAO), then associate researcher at the IFAO. Since January 2017, she has been a Marie Skłodowska-Curie Post-Doctoral Fellow at the University of Copenhagen, Saxo Institute Centre for Textile Research where she leads a project entitled MONTEX: Monks, Nuns and Textiles: Production, Circulation, and Distribution of Textiles in the Monastic Environment in Egypt ( $4^{\text {th }}-8^{\text {th }}$ centuries $\left.A D\right)$. Her interests include various branches of material culture and different aspects of everyday life in Egypt in the Byzantine and Early Arab periods. Her current research focusing on textiles is conducted within the monastic context. These studies are interdisciplinary, combining Greek lexicographical research with archaeological data, as well as an investigation into social history with studies in the history of technology in ancient Egypt. A monograph based on her PhD dissertation, Le vêtement monastique en Égypte (IVe-VIII ${ }^{e}$ siècle), is forthcoming.

Helga Rösel-Mautendorfer studied Celtic studies at the University of Vienna. For her master's degree she worked on textiles from Hallstatt. She took part in the projects HallTexFWF-Dyeing techniques of the prehistoric textiles from the salt mine of Hallstatt (University for Applied Arts Vienna, Archaeometry Department) and HERA: CinBACreativity and Craft Production in Middle and Late Bronze Age Europe (Natural History Museum, Vienna). She has worked on reconstructions of Neolithic, Iron Age and antique garments for the Oberösterreichisches Landesmuseum, Linz. She has published various articles on archaeological textiles and experimental archaeology and collaborated in several exhibitions. Her main research interests are the textiles of prehistory and antiquity, textile techniques, in particular dyeing, experimental archaeology and reconstructions.

Johanna Sigl holds a PhD in egyptology from LudwigMaximilian University, Munich, concentrating on archaeozoology in the area of Aswan. Since her time as a master's student at the same university she has researched looms from Early Christian contexts in Egypt, using the excavated remains for reconstructions of the weaving apparatus of the first millennium AD. Since 2014 she has been a research fellow at the German Archaeological Institute (DAI) in Cairo, with responsibility for archaeological work on Elephantine Island as well as for departmental public relations. She is director of the research project Realities of Life investigating Middle Kingdom settlement structures through refined methods with a focus on reconstructing daily-life realities in the Pharaonic town of Elephantine around 1800 BC. In summer 2019 she took up the post of project coordinator for the DFG-funded project group Entangled Africa at the DAI's commission for Archaeology of Non-European Cultures in Bonn. 